\title{
SPIRIT PENGEMBANGAN KEWIRAUSAHAAN DI PERGURUAN TINGGI
}

\author{
Heri Erlangga \\ FISIP Univeritas Pasundan Bandung \\ heri.erlangga@unpas.ac.id
}

\begin{abstract}
ASBTRACT
The selection of this title was based on the anxiety towards entrepreneurship education phenomenon in hinger institutions which has only been introduced in 1900s. The number of universities and higher institutions in big cities offering at least on class of entreprenenurship is increasing every year; however, hinger institutions are still limited to merely creating graduates as job seekers instead of graduates as job creators. Further, the lack of integration between entrepreneurship education and the structure of curriculum causes problems related to entrepreneurship mental; separated itself from the industry sector, and causes lack of orientation to business development and business opportunities. The issue raised in this research is related to the strategy and development of entrepreneurship program focusing on Philosophical Problematic; entrepreneurship meaning-building, Process Problematic: entrepreneurship development policy, Result Problematic: the impact of entrepreneurship development, Strategy Problematic: the search for model and strategy of entrepreneurship development in higher institutions. The research employed qualitative approach; the data collection was conducted through interview techniques and observation. The results of the research show that in terms of philosophical aspect: (1) the understanding towards entrepreneurship meaning is still in the area of practical approach; (2) the benefit of the entrepreneurship program could increase students confidence to be independent; (3) the entrepreneurship program is the media to provide the values of Independency and Confidence, Creative and Innovative Skill; from the Aspect of Process; (4) the entrepreneurship program can be studied from the aspect of Curriculum; (5) a special policy on entrepreneurship program has not been established; in terms of Result Aspect; (6) entrepreneurship development gives meaningful impact on changing ways of thinking and work governance; in terms of Aspect of Strategy; (7) entrepreneurship strategy and development in higher institutions have not yet been established. The conclusions are: (1) there is a narrow meaningbuilding towards entrepreneurship, a view saying that entrepreneurship is identical with what an entrepreneur or a businessman with a corporate has; (2) entrepreneurship development program is conducted through, one of them, the implementation of entrepreneurship course subject into the curriculum structure which strenghthens the "soul" of entrepreneurship; (3) the implementation and administration of entrepreneurship program still face challenges, in part because of people's incorrect view on university entrepreneurship; (4) entrepreneurship strategy and development requires Business Incubator Model (INBIS), functioning on incubating business potency, which in turn could create Technopreneurship (modern knowledge and technology based entrepreneurship.
\end{abstract}

\section{Keywords: Spirit Entrepreneurship in Higher Institutions}




\section{Abstrak}

Penelitian ini didasarkan pada kegelisahan terhadap fenomena pendidikan kewirausahaan di institusi perguruan tunggi yang baru diperkenalkan pada 1900-an. Jumlah universitas dan institusi yang lebih tinggi di kota-kota besar yang menawarkan setidaknya pada kelas kewirausahaan meningkat setiap tahun; Namun, institusi perguruan tinggi masih terbatas hanya pada menciptakan lulusan sebagai pencari kerja, bukan lulusan sebagai pencipta pekerjaan. Kurangnya integrasi antara pendidikan kewirausahaan dan struktur kurikulum menyebabkan masalah yang berkaitan dengan mental kewirausahaan; memisahkan diri dari sektor industri, dan menyebabkan kurangnya orientasi pada pengembangan bisnis dan peluang bisnis. Masalah yang diangkat dalam penelitian ini terkait dengan strategi dan pengembangan program kewirausahaan yang berfokus pada masalah philosofis; pengembangan makna kewirausahaan, Proses Bermasalah: kebijakan pengembangan kewirausahaan, Masalah Bermasalah: dampak pengembangan kewirausahaan, Strategi Bermasalah: pencarian model dan strategi pengembangan kewirausahaan di institusi yang lebih tinggi. Penelitian ini menggunakan pendekatan kualitatif; pengumpulan data dilakukan melalui teknik wawancara dan observasi. Hasil penelitian menunjukkan bahwa dari segi aspek filosofis: (1) pemahaman terhadap makna kewirausahaan masih dalam bidang pendekatan praktis; (2) manfaat dari program kewirausahaan dapat meningkatkan kepercayaan diri siswa untuk mandiri; (3) program kewirausahaan adalah media untuk memberikan nilai-nilai Kemandirian dan Keyakinan, Keterampilan Kreatif dan Inovatif; dari Aspek Proses; (4) program kewirausahaan dapat dipelajari dari aspek Kurikulum; (5) kebijakan khusus tentang program kewirausahaan belum ditetapkan; dalam hal Aspek Hasil; (6) pengembangan kewirausahaan memberikan dampak yang berarti pada perubahan cara berpikir dan tata kelola kerja; dalam hal Aspek Strategi; (7) strategi dan pengembangan kewirausahaan di institusi yang lebih tinggi belum ditetapkan. Kesimpulannya adalah: (1) ada pembangunan makna yang sempit terhadap kewirausahaan, pandangan yang mengatakan bahwa kewirausahaan identik dengan apa yang dimiliki oleh pengusaha atau pengusaha dengan perusahaan; (2) program pengembangan kewirausahaan dilakukan melalui, salah satunya, penerapan mata pelajaran kewirausahaan ke dalam struktur kurikulum yang memperkuat "jiwa" kewirausahaan; (3) implementasi dan administrasi program kewirausahaan masih menghadapi tantangan, sebagian karena pandangan orang yang salah tentang kewirausahaan universitas; (4) strategi dan pengembangan kewirausahaan membutuhkan Model Inkubator Bisnis (INBIS), yang berfungsi untuk menginkubasi potensi bisnis, yang pada gilirannya dapat menciptakan Technopreneurship (kewirausahaan berbasis pengetahuan dan teknologi modern.

\section{Kata Kunci: Spirit Kewirausahaan, Perguruan Tinggi}

\section{PENDAHULUAN}

Dunia pendidikan tinggi Indonesia mengenal tiga fungsi atau Tri Dharma Perguruan Tinggi, yaitu Pendidikan dan Pengajaran, Penelitian, Pengabdian pada Masyarakat. Apakah fungsi pendidikan tinggi kita sudah memadai didasarkan kepada konsep tridharma tersebut? Dengan adanya suatu visi baru mengenai masa depan yang menuntut fungsi dan peranan perguruan tinggi yang baru, maka ada baiknya menggali kembali dasar-dasar prinsip tridharma tersebut. 
Perumusan mengenai peranan dan fungsi pada pendidikan tinggi telah banyak dirumuskan di dalam pertemuan-pertemuan Internasional. "Kesenjangan mutu pendidikan masih menjadi kendala banyak negara, khususnya Indonesia," kata Asisten Direktur Jenderal untuk Pendidikan dari The United Nations Educational, Scientific and Cultural Organization (UNESCO), Qian Tang, dalam peluncuran Global Education Monitoring (GEM) Report $2016 \mathrm{di}$ Jakarta, Selasa (6/9). Kualitas dan mutu perguruan tinggi di Indonesia masih rendah sehingga sulit bersaing di tingkat internasional. Berdasarkan data dari Kementerian Riset, Teknologi dan Pendidikan Tinggi (Kemenristekdikti), hanya ada 2 perguruan tinggi nasional yang masuk dalam ranking 500 perguruan tinggi terbaik di dunia.

Misi pendidikan tinggi sebagai pusat pengembangan profesionalisme mengisyaratkan bahwa pendidikan tinggi tidak terlepas dari pengembangan dunia industri. Hubungan antara pendidikan tinggi dan industri semakin lama semakin erat bahkan pendidikan tinggi masa depan tidak dapat berdiri sendiri tanpa dunia industri. Pengembangan profesionalisme juga berarti pendidikan tinggi memberikan servis kepada masyarakat sekitarnya dalam rangka membangun suatu masyarakat yang maju, yang berdasarkan teknologi dan ilmu pengetahuan. Dengan demikian pendidikan tinggi yang bertengger di atas menara gading tidak mempunyai tempat dalam abad 21.

Lahirnya Undang-undang Nomor. 20 Tahun 2003 tentang Sistem Pendidikan Tinggi Nasional, yang salah satu peraturan pelaksanaannya yaitu tentang perguruan tinggi telah dirumuskan mengenai fungsi pendidikan tinggi. Di dalamnya juga telah dirumuskan tujuan pendidikan tinggi, yaitu; 1) Menyiapkan peserta didik menjadi anggota masyarakat yang memiliki kemampuan akademik dan atau profesi; 2) Mengembangkan dan menyebarluaskan ilmu pengetahuan serta mengupayakan penggunaannya untuk meningkatkan taraf kehidupan masyarakat dan memperkaya kebudayaan nasional. Peraturan Pemerintah tentang pendidikan tinggi tentunya mengacu pula kepada tujuan pendidikan nasional, yaitu pembentukan manusia seutuhnya. Pada peraturan pemerintah tersebut, lebih menekankan kepada fungsi pendidikan tinggi yang terangkum dalam tridharma perguruan tinggi.

Universitas masa depan dituntut menjalin network dengan dunia industri juga lembaga pendidikan tinggi regional dan internasional. Hal ini didorong oleh, bukan saja karena ilmu pengetahuan yang bersifat universal, juga karena lapangan kerja para ilmuwan akan bersifat global. Selanjutnya universitas dapat memahami patologi kebudayaan industri serta indikasi dari revolusi informasi. Di dalam perubahan global dewasa ini muncul masalah perkembangan dunia ketiga yang tidak kurang menariknya untuk ditangani oleh dunia pendidikan tinggi. Dalam globalisasi muncul jenis budaya baru dan mentalitas baru. Dengan demikian pendidikan tinggi abad 21 meminta suatu budaya kampus yang baru dalam memasuki Revolusi Industri 4.0.

\section{A. Pendidikan Tinggi dan Daya Saing Bangsa}

Daya saing bangsa hanya bisa dicapai apabila terdapat fondasi kesatuan dan persatuan bangsa yang kuat. Perguruan 
tinggi dapat menjalankan peran yang signifikan menjadi pemersatu bangsa melalui penyelenggaraan pendidikan yang berkualitas dan memberikan kesempatan yang luas bagi seluruh bangsa, penelitian yang mampu menggali potensi lokal dan memberikan manfaat bagi masyarakat luas. Meskipun pertumbuhan angka partisipasi kasar jumlah mahasiswa di Indonesia mengalami peningkatan menjadi di atas $32,5 \%$ pada tahun 2017/2018 sedangkan target tahun 2019 di angka 35\%, akan tetapi dibandingkan negara-negara ASIA lainnya posisi tersebut masih tergolong rendah, misalnya dibandingkan Korea Selatan mencapai angka 92\%. Kesempatan untuk mengikuti pendidikan tinggi dan jumlah mahasiswa harus ditingkatkan secara kontinyu dan merata, agar mampu menghasilkan lulusan dalam jumlah yang memadai untuk mampu mendorong pertumbuhan ekonomi dan daya saing bangsa. Peningkatan kuantitas tersebut harus dibarengi dengan peningkatan kualitas dan relevansi yang tinggi. Tanpa kedua aspek tersebut para lulusan yang dihasilkan akan menjadi penganggur intelektual.

Tingkat persaingan sumber daya manusia di pasar kerja nasional maupun internasional terus meningkat seiring dengan peningkatan pemanfaatan ilmu pengetahuan dan teknologi baru pada berbagai bidang dunia usaha, serta kebutuhan tingkat profesionalisme (knowledge, hard skills, soft skills) yang semakin tinggi. Usaha peningkatan kualitas lulusan perguruan tinggi di Indonesia berbeda dengan masa sebelumnya karena pasar terbuka (open market) telah menyebabkan penetrasi tenaga kerja luar negeri akan semakin besar, sehingga persaingan di tingkat nasional tidak lagi terjadi hanya antar lulusan perguruan tinggi nasional saja, melainkan juga antar lulusan perguruan tinggi nasional dengan lulusan perguruan tinggi dari luar negeri.

Badan Pusat Statistik (BPS) merilis laporan jumlah angkatan kerja di Indonesia pada Februari 2017. Dalam periode tersebut, tercatat sebanyak 131,55 juta orang angkatan kerja atau naik 3,88 juta orang dibandingkan Februari 2016. Dari jumlah itu, penduduk Indonesia yang bekerja pada Februari 2017 tercatat sebanyak 124,54 juta orang, naik 3,89 juta orang dibandingkan periode yang sama tahun lalu. Sementara jumlah pengangguran tercatat sebanyak 7,01 juta orang, hanya berkurang 10 ribu orang dibandingkan Februari 2016.

Kompetisi pencari kerja dari lulusan perguruan tinggi semakin ketat karena angka pengangguran di Indonesia terus meningkat, hal ini menuntut perhatian penyelenggara pendidikan tinggi untuk selalu melakukan penyesuaian kurikulum, proses dan materi pembelajaran terhadap perkembangan dunia kerja. Peningkatan relevansi pendidikan ini sebaiknya menjadi sasaran dari peningkatan kualitas yang terus menerus (continuous quality enhancement) sebagai bagian dari suatu sistem penjaminan mutu (quality assurance system) perguruan tinggi secara keseluruhan. Dalam hal ini, aspek relevansi menuntut penyelenggara pendidikan tinggi untuk mengembangkan program studi yang sesuai dengan kebutuhan pasar kerja.

Kualitas dan relevansi merupakan dua aspek pendidikan tinggi yang saling berkaitan dan mempunyai kontribusi langsung pada peningkatan daya saing bangsa dalam bidang sumber daya 
manusia. Mempercepat peningkatan kedua aspek tersebut, perguruan tinggi dapat mengupayakan cooperation, benchmarking, networking atau berbagai usaha lain, sehingga dapat memanfaatkan lesson learned dan best practices dari perguruan tinggi lain.

Hal ini berarti perlu dikembangkan strategi pembangunan pendidikan untuk memperdayakan manusia. Manusia yang berdaya adalah manusia yang dapat berpikir kreatif, mandiri dan mampu membangun dirinya dan masyarakat. Diperlukan juga pendidikan yang berkualitas dengan bertumpu pada penggunaan ICT dan kewirausahaan.

B. Konsep Dasar Kewirausahaan Pengetahuan Kewirausahaan (entrepreneurship) menurut (Gaffar, 2008) adalah istilah manajemen yang mengandung unsur-unsur keilmuan, sikap, dan praktek. Dalam hal keilmuan perlu adanya kejelasan, isinya apa saja ? Mengenai sikap, apakah ada kebijakan yang mendukungnya? sedangkan penjelasan praktek, apakah pasar membutuhkannya?.

Ilmu kewirausahaan adalah suatu disiplin ilmu yang mempelajari tentang nilai, kemampuan (ability) dan perilaku seseorang dalam menghadapi tantangan hidup untuk memperoleh peluang dengan berbagai risiko yang mungkin dihadapinya. Kewirausahaan bukan hanya urusan lapangan, tetapi merupakan disiplin ilmu yang dapat dipelajari dan diajarkan, "Entrepreneurship are not only born but also made", artinya kewirausahaan tidak hanya bakat bawaan sejak lahir atau urusan pengalaman lapangan, tetapi juga dapat dipelajari dan diajarkan. Seseorang yang memiliki bakat kewirausahaan dapat mengembangkan bakatnya melalui pendidikan. Mereka yang menjadi entrepreneur adalah orang-orang yang mengenal potensi (traits) dan belajar mengembangkan potensi untuk menangkap peluang serta mengorganisir usaha dalam mewujudkan cita-citanya.

Kewirausahaan

(entrepreneurship) adalah proses penciptaan sesuatu yang baru pada nilai menggunakan waktu dan upaya yang diperlukan, menanggung risiko keuangan, fisik, serta risiko sosial yang mengiringi, menerima imbalan moneter yang dihasilkan, serta kepuasan dan kebebasan pribadi. Selanjutnya, entrepreneur akan merespon dan menciptakan perubahan melalui tindakan kewirausahaan (entrepreneurial action) mereka, sedangkan tindakan wirausaha mengacu pada perilaku sebagai bentuk tanggapan atas keputusan yang didasarkan pada pertimbangan ketidakpastian mengenai peluang yang mungkin untuk mendapatkan keuntungan.

Secara konseptual, sistem penyelenggaraan pendidikan tinggi yang berorientasi entrepreneurship merupakan sintesis sistem pendidikan yang berorientasi human investment. Adapun lulusan perguruan tinggi yang berorientasi entrepreneurship menjadikan nilai-nilai kewirausahaan sebagai etos kerja civitas akademika yang memiliki sikap, pandangan, pola pikir, dan tindakan yang bercirikan karakteristik manusia wirausaha, yang meliputi : (1) percaya diri; (2) berorientasi tugas dan hasil; (3) berani mengambil resiko; (4) berjiwa kepemimpinan; (5) berorientasi ke masa depan; (6) orisinalitas (Meredith,et.al) dalam (Alma, 2008:290). Kebulatan integratif untuk memiliki karakteristik wirausaha, selanjutnya akan menjadi 
etos kerja kewirausahaan pada perguruan tinggi.

\section{Perkembangan Kewirausahaan}

Dilihat dari perkembangannya, pada tahun 1950-an pendidikan kewirausahaan mulai dirintis di beberapa negara seperti di Eropa, Amerika, dan Canada. Bahkan sejak tahun 1970-an banyak universitas yang mengajarkan "entrepreneurship" atau "small business management" atau "new venture management". Pada tahun 1980-an, hampir 500 sekolah di Amerika Serikat memberikan pendidikan kewirausahaan.

Sejak awal abad ke-20, menurut Hisrich, Robert. D, Peter, Michael. P, Shepherd, Dean. A. (2008:8). kewirausahaan sudah diperkenalkan di beberapa negara. Misalnya; di Belanda dikenal dengan "ondernemer", di Jerman dikenal dengan "unternehmer". Di beberapa negara, kewirausahaan memiliki banyak tanggungjawab antara lain dalam mengambil keputusan yang menyangkut kepemimpinan teknis, kepemimpinan organisasi dan komersial, penyediaan modal, penerimaan dan penanganan tenaga kerja, pembelian, penjualan, pemasangan iklan, dan lain-lain.

Di Indonesia, pendidikan kewirausahaan pada perguruan tinggi terbilang relatif baru dikenalkan tahun 1990-an, berdasarkan pengamatan, jumlah universitas dan perguruan tinggi di kota-kota besar yang menawarkan sedikitnya satu kelas dalam kewirausahaan meningkat setiap tahun, mata kuliah Kewirausahaan dijadikan sebagai mata kuliah umum, dan terdapat di beberapa kampus program-program kewirausahaan dan kewirausahaan teknologi serta program lainnya yang mengarah pada semangat kewirausahaan, namun sebagian besar Universitas masih parsial menempatkan mata kuliah Kewirausahaan, sehingga penerapannya sebatas mata kuliah kewirausahaan yang masih terbatas pada program studi tertentu (misal: program studi ilmu ekonomi dan manajemen), karena pemahaman yang berkembang di perguruan tinggi di Indonesia masih bersifat pendekatan praktek (konsep praktis).

Meskipun dari sisi konsep masih terbuka untuk didiskusikan, namun perguruan tinggi perlu spirit yang berorientasi kewirausahaan guna menjawab kompleksitas permasalahan di atas, melalui kurikulum mata kuliah kewirausahaan yang terintegrasi dengan basis kompetensi life skill untuk menyiapkan bekal kemandirian bagi peserta didik. Sepakat bahwa 'ruh kewirausahaan' merupakan jawaban paling tepat dalam menjawab permasalahan perguruan tinggi dalam menyiapkan lulusannya.

Tentunya juga merupakan permasalahan bagi perguruan tinggi yang disebabkan tidak diberikannya bekal keilmuan mata kuliah kewirausahaan secara merata dalam perkuliahan di beberapa program studi, sehingga tidak terjadi transfer of knowledge. Dengan demikian, penulisan ini diarahkan untuk mengkaji secara mendalam posisi mata kuliah kewirausahaan untuk dijadikan mata kuliah yang terintegrasi ke dalam semua program studi di masing-masing perguruan tinggi. Memposisikan pengembangan program kewirausahaan untuk tersebar di setiap program studi/jurusan merupakan peranan perguruan tinggi dalam memotivasi para calon sarjananya menjadi entrepreneur. Sehingga dapat menepis kenyataan bahwa sebagian besar 
lulusan perguruan tinggi adalah lebih sebagai pencari kerja (job seeker) daripada pencipta lapangan pekerjaan (job creator). Hal ini bisa jadi disebabkan karena sistem pembelajaran yang diterapkan di berbagai perguruan tinggi saat ini lebih terfokus pada bagaimana menyiapkan para mahasiswa yang cepat lulus dan mendapatkan pekerjaan, bukannya lulusan yang siap menciptakan pekerjaan.

Pengembangan kewirausahaan di perguruan tinggi apabila difokuskan pada program penerapannya di lingkungan civitas akademika perguruan tinggi dapat juga ditelusuri dengan langkah awal ke dalam tiga hal:

1) Apakah terintegrasi pada berbagai program studi yang relevan?

2) Merupakan bagian dari program studi tertentu? dan/atau

3) Sebagai mata kuliah tersendiri atau mata kuliah dasar yang ditawarkan pada semua mahasiswa?

Pengembangan program kewirausahaan di perguruan tinggi lebih diarahkan pada pengamatan penerapan mata kuliah kewirausahaan yang terintegrasi ke dalam kurikulum (adanya transfer of knowledge dan transfer of value), akan tetapi pada pendalamannya sangat terbuka mengamati fenomena-fenomena kewirausahaan dalam program-program lainnya yang bersentuhan dengan semangat kewirausahaan, karena pemahaman keilmuan, mental dan pemahaman praktis merupakan keutuhan pemahaman untuk mengkaji pengembangan kewirausahaan di lembaga-lembaga pendidikan. Sebagai contoh yang dapat diungkap dalam pemahaman program kewirausahaan di perguruan tinggi, antara lain; program pengembangan usaha kampus melalui koperasi mahasiswa dan koperasi karyawan, program penelitian yang menggali tentang potensi ekonomi desa/daerah tertentu, program pengabdian pada masyarakat melalui desa binaan dengan penerapan teknologi tepat guna yang dapat membantu masyarakat dalam mengembangkan usahanya, kerjasama-kerjasama dengan dunia usaha melalui pendirian lembagalembaga keuangan, pendirian waralaba dan dunia industri melalui penawaran jasa konsultan dalam mengerjakan berbagai rintisan proyek-proyek industri atau pengembangan proyek. Keseluruhan program yang telah diamati dipersepsikan lebih berorientasi pada pandangan-pandangan praktis (skill), sehingga penting untuk dikaji dan dipertanyakan dari pandangan keilmuan (transfer of knowledge), serta sikap mental (transfer of value).

D. Pertanyaan-Pertanyaan Mendasar Membedah lebih dalam kajian ini, penulis menjabarkannya melalui pertanyaan-pertanyaan yang diklasifikasikan, sebagai berikut:

Problematik Pertanyaan-I; Filosofis:

1. Apa makna program kewirausahaan di Perguruan Tinggi?

2. Apa manfaat dikembangkannya kewirausahaan di Perguruan Tinggi?

3. Seberapa penting pengembangan kewirausahaan di Perguruan Tinggi?

4. Apakah ada program kewirausahaan di Perguruan Tinggi?

Problematik Pertanyaan-2; Proses:

5. Bagaimana Perguruan Tinggi mengelola program kewirausahaan? 
6. Dalam hal apa program pendidikan (kajian mata kuliah kewirausahaan dalam struktur kurikulum) di Perguruan Tinggi yang menunjang kewirausahaan?

7. Bagaimana kebijakan Perguruan Tinggi terhadap pengembangan mata kuliah kewirausahaan dalam struktur kurikulum fakultas dan jurusan/prodi?

Problematik Pertanyaan - 3; Hasil :

8. Bagaimana kewirausahaan diterapkan dan dilaksanakan pada civitas akademika?

9. Seperti apa dampak dari pengembangan kewirausahaan yang diterapkan di Perguruan Tinggi?

Problematik Pertanyaan - 4; Strategi :

10. Bagaimana strategi dan model pengembangan kewirausahaan di Perguruan Tinggi?

\section{Metode Penelitian}

Penelitian ini menggunakan pendekatan inkuiri naturalistik. Pendekatan ini dipilih karena dianggap lebih cocok dengan karakteristik permasalahan yang diteliti yaitu berkenaan dengan perilaku Kewirausahaan. Inkuiri ilmiah adalah pencarian pengetahuan dengan menggunakan metode yang dikenal dengan pengumpulan data, analisis, dan interpretasi.

Penelitian dengan pendekatan kualitatif menggunakan metode pengumpulan sebanyak mungkin fakta secara detail dan mendalam mengenai satu hal atau gejala sosial guna mendapatkan pengertian tentang sebanyak mungkin sifat dari gejala itu. Pengumpulan keterangan untuk memahami fakta tersebut dilakukan dengan teknik-teknik penelitian seperti wawancara (interview), observasi (observation) termasuk observasi terlibat (participation observation).

Selanjutnya perlu ditegaskan di sini bahwa hakikat atau substansi dari fokus kajian lewat pendekatan kualitatif adalah bersifat abstrak. Itu artinya bahwa yang dipahami itu berwujud pikiran, pengetahuan, keyakinan, perasaan dari masyarakat, kelompok, atau golongan sosial yang diteliti. Semua itu ditelusuri lewat gejala perilaku atau gejala-gejala lainnya. Gejala-gejala yang dapat diamati itu, dianalisis, diinterpretasi dan pada gilirannya harus dapat diterangkan dan difahami sebagai perilaku masyarakat yang bersangkutan. Semua pemahaman ini terkait pada teori yang telah ada dan peneliti akan melakukan interpretasi dan merekonstruksi teori yang akan melahirkan model dalam Pengembangan Kewirausahaan pada Perguruan Tinggi melalui Kajian tentang Pengembangan Program kewirausahaan, sehingga akan memberikan perubahan pemahaman terhadap permasalahan setelah dilakukannya penelitian.

Penelitian ini memfokuskan masalahnya pada manajemen kewirausahaan pada beberapa perguruan tinggi sebagai faktor-faktor stratejik dalam pengelolaan perguruan tinggi yang bermutu. Lebih khusus sikap pengelola perguruan tinggi yang dijadikan sebagai fokus masalah, sedangkan civitas akademika yang lain, secara umum dapat dijadikan sumber pendukung di dalam kajian ini.

Metode yang digunakan dalam penelitian ini adalah kualitatif. Metode ini berdasarkan pada penghayatan terhadap perilaku manusia secara holistik dan utuh. Sehubungan dengan hal ini, Kao (1991:190) menyatakan bahwa wirausaha merupakan gejala 
perilaku. Segala kegiatan yang berlangsung diteliti apa adanya (natural setting) dan diselami melalui metode penghayatan yang mendalam (verstehen) dan dicari nilai-nilai apa yang melekat dalam pengembangan kewirausahaan dengan berbekal pengalaman dan ilmu pengetahuan yang dimiliki. Kegiatan-kegiatan yang paling melembaga (menyatu) dalam pengembangan kewirausahaan. Orangorang yang diteliti dipandang sebagai pusat dari fenomena sosial yang ada. Karena itu, pandangan merekalah yang terpenting (perspektif emic) bukan pandangan peneliti (perspektif etic).

Penelitian dengan pendekatan kualitatif ialah penelitian dengan metode pengumpulan sebanyak mungkin fakta secara detail dan mendalam mengenai satu hal atau gejala sosial guna mendapatkan pengertian tentang sebanyak mungkin sifat dari gejala itu. Pengumpulan keterangan untuk memahami fakta tersebut dilakukan dengan teknik-teknik penelitian seperti wawancara (interview), observasi (observation), termasuk observasi terlibat (participation observation). Sesuai yang diperkuat pendapat Krathwohl (1993:315) di bawah ini:

"Qualitative data may be gathered in as many ways as the researcher's creativity permits. Although the most widely used source is observation, analysis of records and documents is also common. In addition to observation in a sociological tradition, methods of eliciting responses from individuals using interviewing or a stimulated response technique, as psychologists do, may be useful".
Penelitian dengan pendekatan kualitatif ini untuk memahami hakekat dari gejala-gejala sosial dan hubungan antara gejala-gejala yang bersifat holistik dan sistemik. Makna atau pesan tersirat dibalik gejala atau hubungan antar gejala itu harus dipahami dalam kaitannya dengan pokok masalah penelitian. Masalah itu akan dijawab dengan didasarkan pada teori atau kerangka teori tertentu.

Selanjutnya perlu ditegaskan disini bahwa hakikat atau substansi dari fokus kajian lewat pendekatan kualitatif adalah bersifat abstrak. Artinya, bahwa yang dipahami itu berwujud pikiran, pengetahuan, keyakinan, perasaan dari masyarakat, kelompok atau golongan sosial yang diteliti. Semua itu ditelusuri lewat gejala perilaku atau gejala-gejala lainnya. Gejala-gejala yang diamati itu, dianalisis, diinterpretasi dan pada gilirannya harus dapat diterangkan dan dipahami sebagai kebudayaan masyarakat yang bersangkutan.

\section{Pembahasan dan Analisis}

Potret kewirausahaan di perguruan tinggi akan penulis uraikan sebagai hasil penelitian dan pembahasan yang dilakukan di perguruan tinggi dengan uraian yang diklasifikasikan berdasarkan problematik pertanyaanpertanyaan Filosofis, Proses, Hasil dan Strategi/Model yang telah diuraikan pada bab pendahuluan.
1. Penelaahan Makna Program Kewirausahaan di Perguruan Tinggi

Pemahaman terhadap makna kewirausahaan yang berkembang di lingkungan perguruan tinggi berada pada wilayah pendekatan praktis (konsep praktis atau aspek psikomotorik 
dalam makna pembelajaran). Sesungguhnya, pemaknaan kewirausahaan seharusnya memiliki 'ruh' dari mulai konsep keilmuan, konsep sikap dan konsep praktis. Artinya, dalam pemaknaan konsep keilmuan program kewirausahaan dimasukan atau terintegrasi ke dalam kurikulum menjadi mata kuliah mandiri, sehingga ada proses transfer of knowledge dari proses belajar mengajar di kelas, karena itu jika dimaknai kewirausahaan adalah merupakan ilmu pengetahuan, maka penting diajarkan kepada mahasiswa untuk membekali diri agar memiliki modal dalam mengembangkan kemampuan kreativitas dan inovatif. Selain itu juga pentingnya ada transfer of value dalam proses belajar mengajar, karena sikap dimaknai sebagai karakter yang hasil akhirnya akan membentuk sikap-sikap kemandirian dan percaya diri. Meskipun demikian dukungan konsep praktis sangatlah penting dengan adanya aplikasi di lapangan dalam pembentukan unit-unit usaha atau lembaga-lembaga usaha yang dijadikan wahana pembelajaran organisasi usaha untuk civitas akademika, sehingga dapat menumbuhkan Jiwa Kepemimpinan, Profesionalisme, Emotional Intelegence.

Pendapat di atas didasarkan pada konsep ilmu kewirausahaan adalah suatu disiplin ilmu yang mempelajari tentang nilai, kemampuan (ability) dan perilaku seseorang dalam menghadapi tantangan hidup untuk memperoleh peluang dengan berbagai risiko yang mungkin dihadapinya. Kewirausahaan bukan hanya urusan lapangan, tetapi merupakan disiplin ilmu yang dapat dipelajari dan diajarkan. "Entrepreneurship are not only born but also made”, artinya kewirausahaan tidak hanya bakat bawaan sejak lahir atau urusan pengalaman lapangan, tetapi juga dapat dipelajari dan diajarkan. Seseorang yang memiliki bakat kewirausahaan dapat mengembangkan bakatnya melalui pendidikan.

Umumnya masih banyak orang yang menafsirkan dan memandang bahwa kewirausahaan identik dengan apa yang dimiliki dan dilakukan "usahawan" atau "wiraswasta". Pandangan tersebut tidaklah salah namun kurang tepat, karena jiwa dan sikap kewirausahaan (entrepreneurship) tidak hanya dimiliki oleh usahawan akan tetapi dapat dimiliki oleh setiap orang yang berpikir kreatif dan bertindak inovatif baik kalangan usahawan maupun masyarakat umum seperti petani karyawan, pegawai pemerintah, mahasiswa, guru/dosen, dan pimpinan organisasi lainnya.

Kontek pendekatan keilmuan (adanya transfer of knowledge) dari penerapan program mata kuliah kewirausahaan yang diintegrasikan ke dalam kurikulum dapat memperkuat 'ruh' kewirausahaan dalam pola pikir dan cara pandang civitas akademika.

\section{Penelaahan Manfaat Dikembangkannya Program Kewirausahaan di Perguruan Tinggi}

Manfaat dikembangkannya kewirausahaan dapat memberikan spirit terhadap civitas akademika bahwa banyak kampus yang berhasil dan sukses karena manajemen memiliki kemampuan berpikir kreatif dan inovatif. Karya dan karsa hanya terdapat pada manajemen kampus yang terdiri dari orang-orang yang berpikir kreatif. Tidak sedikit kampus yang berhasil 
meraih sukses karena memiliki kemampuan kreatif dan inovatif.

Pengembangan lebih jauh dengan masuknya program kewirausahaan pada perguruan tinggi, memiliki orientasi sebagai berikut:

a. Mendorong pemanfaatan hasil penelitian dan pengembangan menjadi perangkat yang dapat digunakan masyarakat dan bernilai komersial.

a. Mewujudkan sinergi potensi perguruan tinggi dengan potensi industri/usaha kecil menengah sehingga dapat menumbuhkembangkan industriindustri kecil dan menengah yang mandiri.

b. Menumbuh-kembangkan budaya kewirausahaan di dalam lingkungan perguruan tinggi untuk mendorong terciptanya wirausahawan baru.

c. Mendorong akselerasi pemulihan ekonomi (economy recovery) Indonesia melalui penanggulangan kemiskinan dan penyediaan lapangan kerja dengan tumbuhnya wirausahawan baru yang kuat, baik dari segi kualitas barang produksi dan jasa maupun pada aspek pemasarannya.

d. Menumbuh kembangkan kegiatan-kegiatan yang mendorong terwujudnya income generating unit di perguruan tinggi dalam mengantisipasi diberlakukannya otonomi perguruan tinggi (khususnya perguruan tinggi negeri).

Secara sistemik, kewirausahaan sebagai dasar reorientasi manajemen perguruan tinggi, menurut Susanto dalam Alma (2008:296) mencakup dimensi-dimensi proses belajar mengajar, penelitian, dan pengabdian kepada masyarakat. Kewirausahaan dalam penelitian berkenaan dengan kemampuan mengkomunikasikan dunia keilmuan (world of sciences) dan dunia nyata masyarakat luas (real world of society). Membawa isu dan persoalan dunia nyata ke dalam dunia keilmuan memerlukan improvisasi yang kuat. Dalam dimensi pengabdian kepada masyarakat, memasukkan semangat kewirausahaan dapat dilakukan melalui program-program pengabdian masyarakat. Sebagai sarana aplikasi, komunikasi dan sosialisasi hasil pengajaran dan penelitian guna menuju profesionalisme.

Perguruan tinggi dalam mengembangkan kewirausahaan baik dari aspek keilmuan (teoritis), nilai (value) dan praktis merasakan manfaat yang beragam. Kampus membutuhkan spirit manajemen menuju kemandirian dalam pengembangan sarana dan prasarana untuk meningkatkan rasa percaya diri, karena itu nilai-nilai kreativitas dan inovasi adalah menjadi nafas dalam menjalankan tri dharma perguruan tinggi menuju profesionalisme akademik.

3. Pentingnya Pengembangan Kewirausahaan di Perguruan Tinggi

Pentingnya pengembangan program kewirausahaan diterapkan di perguruan tinggi karena memerankan fungsi, sebagai berikut :

a. Mengidentifikasi sistem bisnis yang sudah berjalan dan potensi bisnis di perguruan tinggi, serta membantu dunia usaha yang berpeluang untuk dikembangkan.

b. Menyiapkan potensi bisnis di perguruan tinggi agar menjadi unit-unit bisnis yang mandiri dan 
mampu menjadi sumber pendapatan untuk mendukung kegiatan Tri Dharma Perguruan Tinggi.

c. Membantu pengembangan kewirausahaan civitas akademika dan alumni.

d. Mensinergikan IPTEKS perguruan tinggi dengan kebutuhan dunia usaha.

e. Menguatkan jejaring informasi IPTEKS untuk mendukung keberlanjutan bisnis di perguruan tinggi.

Pengembangan kewirausahaan melalui cara-cara di atas akan lebih terarah dan akan memberikan nilai pembelajaran secara bertahap bagi perguruan tinggi. Sesunggunya fungsi-fungsi di atas dirasakan oleh perguruan tinggi meskipun pada kekuatan yang berbeda, hal ini dilatarbelakangi oleh perbedaan kultur perguruan tinggi yang memiliki perjalanan yang berbeda dalam perkembangannya dari masa ke masa.

\section{Program Kewirausahaan pada Perguruan Tinggi}

Program kewirausahaan pada perguruan tinggi merupakan wadah untuk membekali generasi bangsa agar memiliki nilai-nilai Kemandirian dan Percaya Diri, Kemampuan Kreatif dan Inovatif, Memiliki Jiwa Kepemimpinan, Profesionalisme, Emotional Intelegence.

Hal tersebut dapat dibentuk dengan digulirkannya program kewirausahaan di perguruan tinggi. Program kewirausahaan dalam perkembangannya masih mencari bentuk program yang sesuai dengan 'ruh' dan 'aura' akademik perguruan tinggi dalam dinamika yang sangat berbeda, namun demikian hal penting dalam program kewirausahaan adalah bagaimana munculnya ide-ide dan pemikiran-pemikiran baru untuk menciptakan sesuatu yang baru dan berbeda. Dalam organisasi kampus umumnya, proses kreatif dan inovatif dapat dilakukan melalui kegiatan penelitian dan pengembangan (research and development) untuk meraih pasar.

Keunggulan di segala bidang sulit diwujudkan di perguruan tinggi pada waktu yang bersamaan. Oleh karena itu, strategi pengembangan pendidikan tinggi diarahkan pada pemberian peluang kepada perguruan tinggi yang mempunyai potensi dan kapasitas untuk mengembangkan dirinya meraih keunggulan kompetitif, yakni keunggulan akademik (academic excellence). Berdasarkan kenyataan tersebut, maka kampus harus ditingkatkan kemampuannya untuk mengikuti berbagai perubahan dan mengejar ketertinggalan. Usaha ini dapat dilakukan apabila paradigma perguruan tinggi berubah menjadi perguruan tinggi yang mandiri dan otonom serta tidak selalu tergantung pada anggaran pemerintah.

Kunci keberhasilan untuk kemandirian adalah menjadikan perguruan tinggi menjadi research university sekaligus entrepreneurial university seperti yang telah berkembang di negara-negara maju. Upaya tersebut dapat terlaksana apabila segala potensi akademik maupun nonakademik yang ada di perguruan tinggi dapat dikembangkan menjadi unit bisnis melalui kerjasama dengan dunia usaha dan dunia industri yang dapat tercapainya akselerasi link and match. Meskipun hal tersebut membutuhkan adaptasi yang sinergis bagi perguruan tinggi, namun dengan menggerakan 
semua potensi yang dimiliki, keberhasilan akan tercapai.

\section{Pengelolaan \\ Program \\ Kewirausahaan di Perguruan Tinggi}

Pengelolaan program kewirausahaan dari segi ilmu dan praktis, bahwa Perguruan tinggi akan memiliki sumber penghasilan dan infrastruktur yang dapat mengembangkan kemampuannya melebihi dari apa yang dimiliki. Dengan demikian, perguruan tinggi secara signifikan dapat meningkatkan reputasi dan kualitasnya sesuai dengan kebutuhan pasar.

Mengelola program entrepreneur university perlu mempelajari yang sudah melakukannya, melalui Strategic Benchmarking yang diartikan : "Merupakan pencarian dan aplikasi praktek-praktek yang benar-benar lebih baik secara terus-menerus, yang mengarah pada kinerja kompetitif yang superior". (Gregory H. Watson, 1997:2).

Benchmarking merupakan proses pengukuran yang sistematis dan berkesinambungan; proses mengukur dan membandingkan secara sinambung atas proses-proses bisnis suatu organisasi dengan tokoh-tokoh proses bisnis manapun di seluruh dunia, untuk mendapatkan informasi yang akan membantu upaya organisasi tersebut memperbaiki kinerjanya.

Benchmarking mengikuti pendekatan dasar empat langkah, yang mengikuti metode mutu fundamental sebagaimana yang dipaparkan Shewhart, antara lain :

Pada langkah pertama, yakni merencanakan studi Benchmarking, kita perlu menyeleksi dan menentukan proses yang harus dipelajari. Langkah pertama dapat direduksi untuk menjawab dua pertanyaan mendasar:

1) Apa yang harus kita bandingkan ?

2) Perusahaan mana yang harus kita pakai sebagai tolok ukur perbandingan?

Langkah kedua, dalam Benchmarking adalah mengadakan riset primer dan sekunder. Meliputi penyelidikan penyingkapan rahasia atas proses tertentu di dalam perusahaan menjadi sasaran;

Langkah ketiga, dalam Benchmarking adalah menganalisis data yang terkumpul guna menyusun temuan studi dan rekomendasi;

Langkah keempat; Benchmarking meliputi adaptasi, pengembangan dan implementasi faktor penentu proses Benchmarking yang cocok.

Tujuan Benchmarking adalah mengubah suatu organisasi sedemikian rupa sehingga meningkatkan kinerjanya. Dengan demikian, Benchmarking merupakan suatu proses yang sejak awal memiliki bias aksi; ini lebih daripada sekedar studi atas proses bisnis atau studi untuk memperoleh suatu tolok ukur relatif bagi kinerja bisnis.

Pengelolaan program kewirausahaan yang baik dibutuhkan tolok ukur dari perguruan tinggi, fenomena kewirausahaan perguruan tinggi relatif masih dinilai merupakan barang baru bahkan memunculkan kontroversi dalam merespon dan menilai program kewirausahaan perguruan tinggi, sehingga perlu untuk adaptasi dalam menerapkannya dengan melakukan Benchmarking ke beberapa perguruan tinggi yang lebih awal menjalankan program entrepreneur university. Melalui program Benchmarking dimungkinkan program tersebut bisa lebih cepat diadaptasikan 
untuk dijalankan karena perguruan tinggi dapat mengukur kemampuannya dalam mengadopsi program-program yang bisa dilaksanakan.

6. $\begin{array}{rr}\text { Memperjelas Program Pendidikan } \\ \text { (Kajian }\end{array}$ Mata $\quad$ Kuliah Kewirausahaan dalam Struktur Kurikulum) di Perguruan Tinggi

Gambaran tentang program pendidikan yang mengandung kewirausahaan (kajian kurikulum), bahwa dimensi kewirausahaan dalam proses belajar mengajar di perguruan tinggi terkait dengan kurikulum dan sumber daya manusia. Memasukkan semangat kewirausahaan untuk mewarnai muatan lokal dalam kurikulum pendidikan tinggi dapat dipandang sebagai perwujudan perguruan tinggi merespon perkembangan eksternal.

Secara ideal program pendidikan kewirausahaan melalui kajian kurikulum meliputi beberapa mata kuliah, sebagai contoh untuk program studi/jurusan manajemen, meliputi: Kewirausahaan (mata kuliah inti), Pengantar Bisnis, Hukum Bisnis, Administrasi Bisnis/Kantor, Komunikasi Bisnis, Manajemen dan Organisasi, Pengelolaan Keuangan dan Permodalan, Pengelolaan Produksi dan Teknologi, Pengelolaan Pemasaran, Akuntansi Bisnis, Perkoperasian, Hukum Bisnis, Administrasi Bisnis/Kantor, Perbankan, dan mata kuliah lainnya yang memiliki keterkaitan.

Berdasarkan pada kajian-kajian dibeberapa kurikulum, maka pengembangan dari tiap mata kuliah masih dapat dikembangkan lagi sesuai kebutuhan kajian yang saling melengkapi, karena pengembangan nilai-nilai kewirausahaan tidak terlepas dari konteks pengembangan the core curriculum yang diarahkan terbentuknya dimensi-dimensi Nilai Kemandirian dan Percaya Diri, Kemampuan Kreatif dan Inovatif, Memiliki Jiwa Kepemimpinan, Profesionalisme, Emotional Intelegence.

7. Memahami Kebijakan Pengembangan Mata Kuliah Kewirausahaan dalam Struktur Kurikulum

Kebijakan

pengembangan kewirausahaan di perguruan tinggi secara umum akan selalu terkait dengan kebijakan pendidikan. Pengertian kebijakan pendidikan dirumuskan Tilaar dan Riant Nugroho (2008:140), sebagai berikut: "Kebijakan pendidikan merupakan keseluruhan proses dan hasil perumusan langkah-langkah strategis pendidikan yang dijabarkan dari visi, misi pendidikan, dalam rangka untuk mewujudkan tercapainya tujuan pendidikan dalam suatu masyarakat untuk suatu kurun waktu tertentu".

Menurut Tilaar dan Riant Nugroho (2008:140) kebijakan perguruan tinggi yang merupakan bagian dari kebijakan pendidikan, apabila dirumuskan kebijakannya terhadap pengembangan program kewirausahaan dapat diarahkan pada hal-hal sebagai berikut:

1) First, the public-service institution needs a clear definition of its mission.

2) The public-service institution needs a realistic statement of goals.

3) Failure to achieve objective should be considered an indication that the objective is wrong, or at least defined wrongly. 
4) Finally, public-service institutions need to build into their policies and practices the constant search for innovative opportunity.

Kebijakan kewirausahaan berimplikasi terhadap layanan publik karenanya misi perguruan tinggi menuju kewirausahaan sangat penting bagi universitas yang memiliki keberanian menanggung resiko jika memulai suatu yang baru hasilnya belum pasti. Perguruan tinggi sebagai badan usaha selalu aktif berinovasi dalam melaksanakan usahanya yang secara organisatoris siap berubah untuk membangun postur yang lebih menjanjikan di masa depan. Dengan demikian kewirausahaan perguruan tinggi memerlukan suatu proses dan outcome yang jelas dengan dukungan kebijakan.

8. Kewirausahaan Diterapkan dan Dilaksanakan pada Civitas Akademika

Penerapan dan pelaksanaan program kewirausahaan secara menyeluruh sebagai satu kesatuan yang saling terkait dan bersinergi. Kegiatan entrepreneurial kolektif merupakan inti dari fenomena transformasi universitas. Artinya bahwa semua unit-unit atau pusat-pusat haruslah menjadi pusat bisnis di samping sebagai pusat pelayanan akademis. Entrepreneur kolektif yang efektif tidak akan membawa sebuah universitas melampaui batas-batas legitimasi akademis, tetapi akan menciptakan alur pasar untuk reputasi, sumberdaya dan pengembangan. Prinsipnya program kewirausahaan diterapkan mengikuti tipe kegiatan dalam perguruan tinggi, seperti dilihat pada gambar di bawah ini:

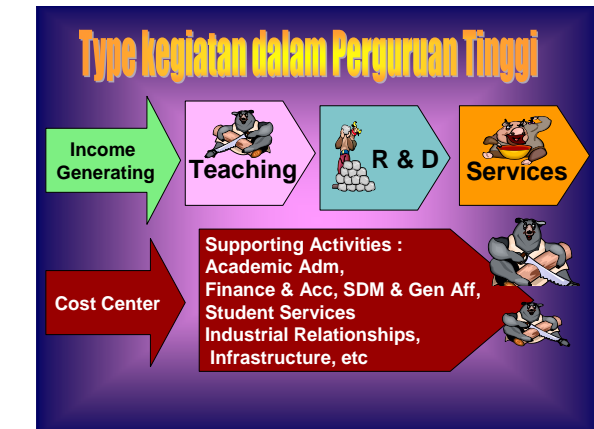

Gambar 4.3. Type Kegiatan dalam Perguruan Tinggi

Sumber : Adopsi HELTS 2003-2010

Kondisi obyektif perguruan tinggi untuk melaksanakan type kegiatan di atas masih belum terpola dengan baik, dalam hal income generating program, walaupun sudah ada program-program yang menghasilkan baik dari program pendidikan dan pengajaran, penelitian dan pengembangan juga dalam pengabdian pada masyarakat, akan tetapi masih berskala kecil dan belum berkesinambungan. Termasuk dalam pembiayaan yang terpusat untuk program-program yang menunjang pengembangan kewirausahaan masih belum terfokus atau masuk dalam skala prioritas.

9. Dampak Pengembangan Kewirausahaan yang Diterapkan di Perguruan Tinggi

Tidak ada satu ukuran yang dapat digunakan untuk mengukur dampak keberhasilan perguruan tinggi dalam pengembangan kewirausahaan di kampus kecuali kinerjanya yang tinggi dalam pengajaran dan penelitian di atas indikator tatanan sosial lainnya. Hal tersebut dapat saja diukur berdasarkan tren manajemen yang dapat mengguncang dunia bisnis, yaitu: Siklus Mutu, yang bertahan lebih dari beberapa tahun; Budaya Perusahaan/organisasi, menjadi proses yang rumit dan mahal; Intrapreneuring, di dalam perusahaan 
memajukan semangat kewirausahaan dalam merealisasikan gagasan yang bagus; Partisipasi Karyawan, dengan sistem rotasi yang inovatif; Aliansi Strategis, menciptakan persekutuan yang aneh; Manajemen dengan Berjalan Berkeliling, taktik mengamati secara langsung apa yang sedang terjadi di lapangan; Manajemen Perubahan, konsep mengelola perubahan disajikan kepada perusahaan walaupun perubahan adalah sesuatu yang baru dan mengelola perubahan adalah ilmu pengetahuan.

Dalam sistem pendidikan tinggi, keberagaman visi dan misi adalah sangat penting, dan universitas didorong atau didanai untuk berperan sebagaimana yang diharapkan. Mengukur dampak yang dimaksud dapat kita lihat pada pengembangan organisasi yang berorientasi hasil sebagai pedoman dalam pengembangan organisasi kampus menuju entrepreneur university.

Sebagaimana penjabaran visi, misi di tingkatan Universitas, Fakultas dan Jurusan/Prodi yang mencantumkan semangat kewirausahaan belum dimiliki secara khusus terhadap penjabaran visi, misi dalam rangka memperkuat semangat kewirausahaan. Sehingga dampaknya terhadap penerapan mata kuliah kewirausahaan untuk dimasukan dalam struktur kurikulum fakultas dan jurusan/prodi masih relatif rendah apalagi pada bidang yang lain. Karena itu, penting bagi manajemen perguruan tinggi untuk menelaah pengembangan organisasi berorientasi hasil sebagai evaluasi terhadap visi, misi, aturan, profesionalisme, insentif, sumber daya, dan rencana kerja, seperti yang terlihat dalam gambar :

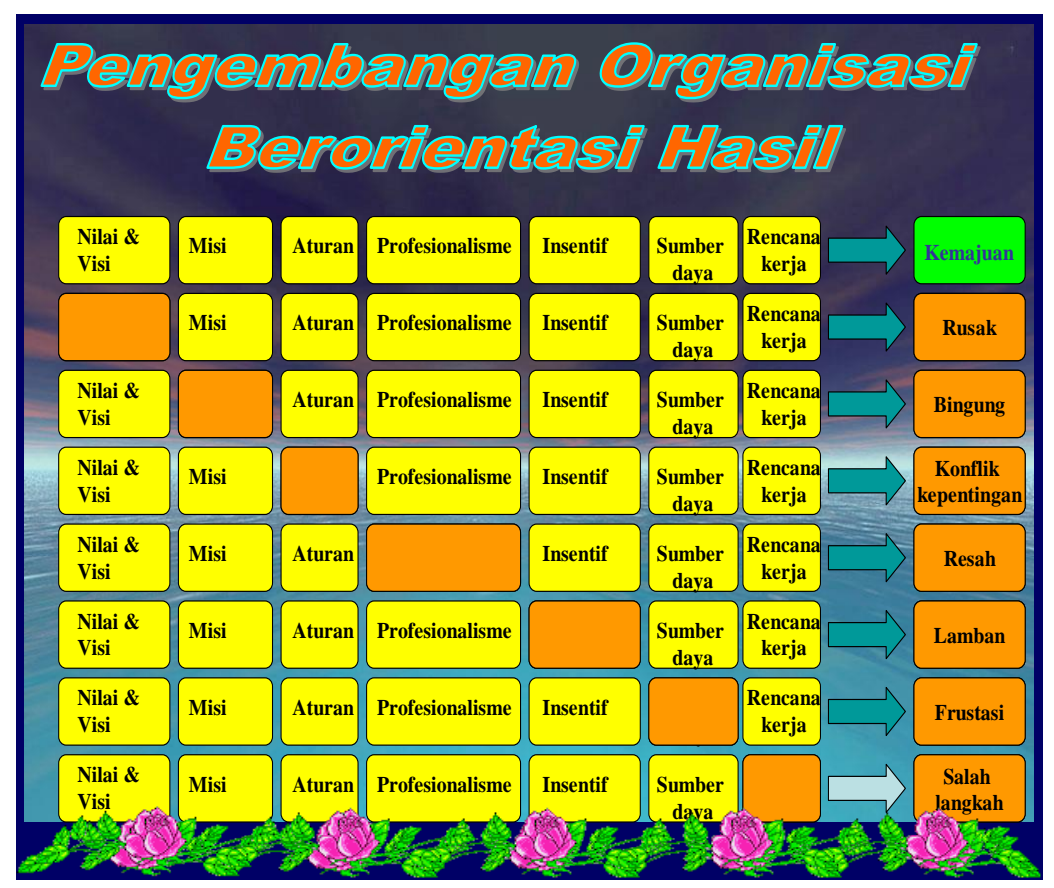

Gambar 4.4. Pengembangan Organisasi Berorientasi Hasil

Sumber : Adopsi Visi, Misi dan Strategi Organisasi Perguruan Tinggi (Margianti, 2008:10) 
10. Strategi dan Model Program Kewirausahaan di Perguruan Tinggi?

Strategi/model program kewirausahaan perguruan tinggi yang sesuai dalam mewujudkan research university yang sekaligus sebagai entrepreneurial university adalah strategi Manajemen Program Kewirausahaan dan Inkubator Bisnis (INBIS) Perguruan Tinggi yang diharapkan mampu memadukan potensi bisnis non-akademik maupun akademik (misal: hasil-hasil riset) dengan bisnis melalui pengembangan budaya kewirausahaan di perguruan tinggi dengan cara:

a. Menumbuhkembangkan budaya kewirausahaan dalam tridharma PT.

b. Mewujudkan sinergi potensi perguruan tinggi dengan potensi dunia usaha sehingga dapat menumbuhkembangkan IPTEKS sesuai kebutuhan.

c. Memanfaatkan potensi bisnis akademik/non-akademik bernilai komersial.

d. Meningkatkan peluang keberhasilan wirausaha baru melalui kegiatan pelayanan konsultasi terpadu.

e. Menumbuhkembangkan kegiatankegiatan yang mendorong terwujudnya unit-unit usaha sebagai sumber pendapatan (income generating unit) di perguruan tinggi perlu diciptakan strategi dan model pemahaman agar tidak terjebak pada pandangan sempit dan praktis. Adapun strategi/model spirit kewirausahaan dapat ditelaah dalam gambar di bawah ini:

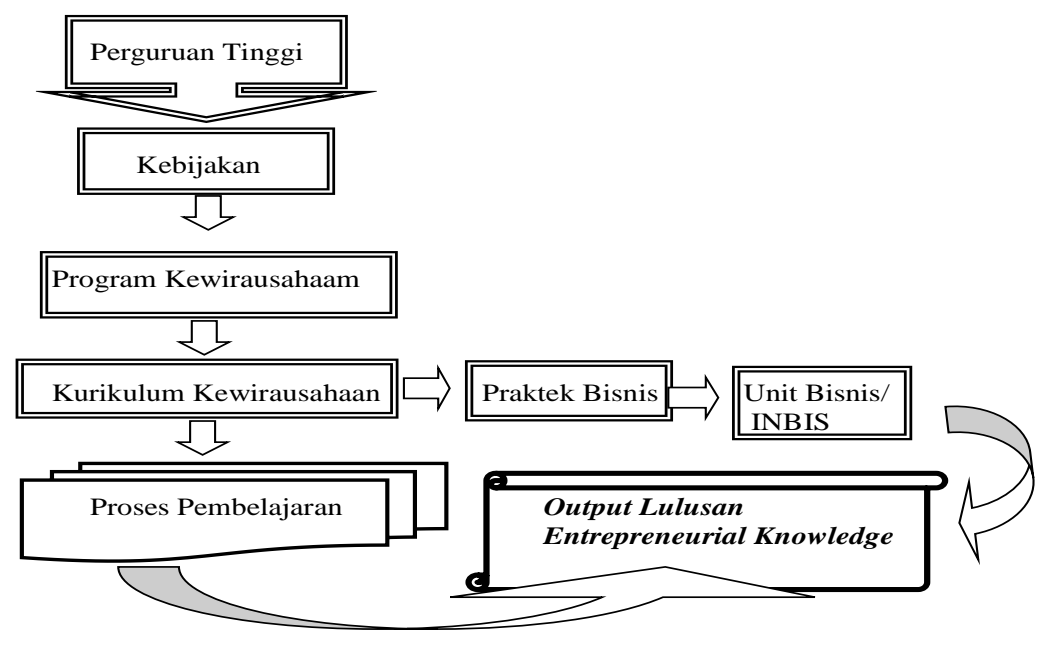

\section{Gambar 4.5.a. Strategi/Model Program Spirit Kewirausahaan di Perguruan Tinggi}

$\begin{array}{lrrr}\text { Adapun strategi } & \text { dan } & \text { model } \\ \text { INBIS yang } & \text { mendukung } \\ \text { berkembangnya } & \text { potensi } & \text { bisnis }\end{array}$

perguruan tinggi dapat digambarkan di bawah ini: 


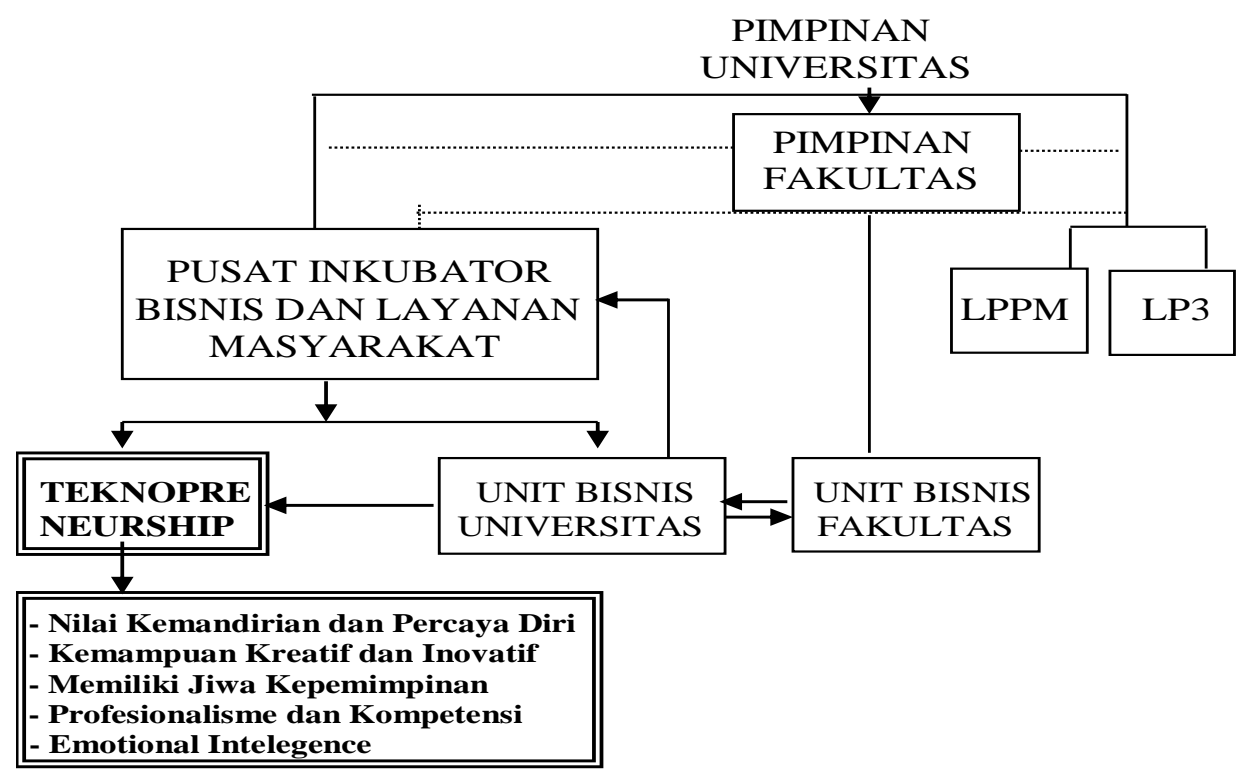

Gambar 4.5.b. Model INBIS dalam Struktur Organisasi Perguruan Tinggi

Model inkubator bisnis ini akan melahirkan teknopreneurship, artinya Teknopreneur (entrepreneur modern) yang berbasis teknologi: "KeEntrepreneuran-nya berdasarkan keahlian berbasis pendidikan dan pelatihan yang didapatkannya dibangku perkuliahan ataupun dari percobaan pribadi". Mereka menggunakan teknologi sebagai unsur utama pengembangan produk suksesnya, bukan sekedar jaringan, lobi, dan pemilihan pasar secara demografis. Seorang Teknopreneur yang lahir dari kampus telah memiliki modal: Kreativitas, Inovasi, Komitmen, dan Kompetensi.

Kondisi obyektif dari perguruan tinggi yang sedang melakukan kompetitif, jika diamati dalam penerapan konsep model kewirausahaan belum terlihat adanya hal yang khusus karena biasanya dari struktur perguruan tinggi belum menempatkan struktur yang bertanggungjawab dalam pengembangan kewirausahaan di perguruan tinggi, meskipun model di atas dapat dirujuk menjadi model penerapan pengembangan kewirausahaan, akan tetapi kembali kepada pimpinan perguruan tinggi, apakah memiliki semangat untuk lebih memfokuskan dan memprioritaskan program inkubasi bisnis?. Penerapan model Inkubator Bisnis merupakan model yang tidak bisa ditunda oleh perguruan tinggi, karena dengan adanya unit khusus yang memikirkan dan mengembangkan program kewirausahaan di kampus akan dapat menggali potensi bisnis perguruan tinggi dan dunia usaha, selain itu juga banyak membantu melakukan pembinaan, bimbingan serta fasilitasi manajemen antara civitas akademika, penerapan teknologi tepat guna, permodalan bergulir, dan pemasaran terhadap potensi bisnis perguruan tinggi sehingga akan melahirkan unit-unit bisnis yang mandiri. Perguruan tinggi yang memiliki inkubator bisnis akan mampu melahirkan calon sarjana yang 
memiliki jiwa wirausaha yang ditunjang dengan kemampuan ilmu pengetahuan dan teknologi yang diharapkan kaya dengan kreativitas dan inovasi sesuai bidang ilmu masing-masing atau gabungan dengan modal bakat dan pengalaman. Dengan berjalannya program kewirausahaan pada perguruan tinggi akan banyak memunculkan Teknopreneurship, seseorang yang memulai usaha dengan bekal ilmu, sehingga memiliki daya nalar yang tinggi dan analisa yang tajam dalam melihat setiap peluang maupun ancaman, melalui kajian SWOT Analysis, seperti gambar di bawah ini:
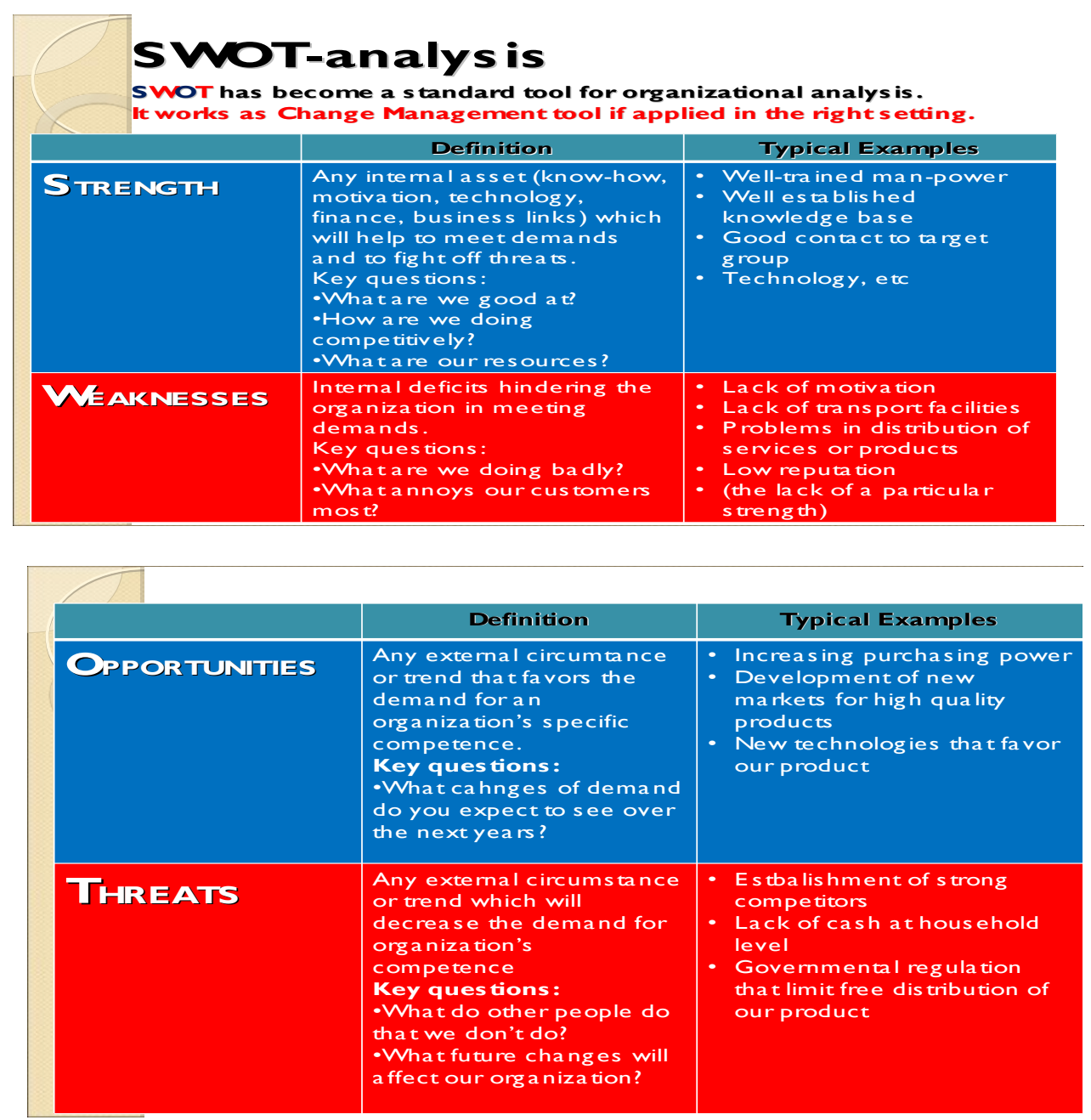

Gambar 5.7. SWOT Analysis (Freddy, 1999)

Pemahaman yang mendalam terhadap SWOT Analysis merupakan bagian yang tidak terpisahkan dalam strategi pengembangan organisasi perguruan tinggi karena dapat juga dijadikan sebagai analisis spirit kewirausahaan di perguruan tinggi untuk mengukur kekuatan, kelemahan, peluang dan ancaman.

\section{Kesimpulan dan Rekomendasi \\ A. Kesimpulan}

Sebagaimana dari hasil analisis tentang spirit kewirausahaan di Perguruan Tinggi yang telah dibahas, maka penulis 
menarik kesimpulan dari hasil pembahasan dengan mengacu secara khusus pada problematik pertanyaanpertanyaan Filosofis, Proses, Hasil dan Strategi, dengan kesimpulan sebagai berikut:

\section{Problematik Filosofis;}

Pemaknaan yang berkembang tentang kewirausahaan dapat diapresiasi dalam pemahaman praktis (konsep praktis), hal ini terungkap karena pemaknaan sempit yang ada terhadap kewirausahaan adalah penafsiran dan memandang bahwa kewirausahaan identik dengan apa yang dimiliki dan dilakukan "usahawan" atau "wiraswasta" yang memiliki usaha (berdagang). Pandangan tersebut tidaklah salah, namun kurang tepat, karena jiwa dan sikap kewirausahaan (entrepreneurship) tidak hanya dimiliki oleh usahawan akan tetapi dapat dimiliki oleh setiap orang yang berpikir kreatif dan bertindak inovatif. Pemahaman inilah yang dapat dirasakan manfaatnya dengan dikembangkannya kewirausahaan di perguruan tinggi, sehingga tulisan ini diharapkan mendapatkan dukungan dan tanggapan yang baik. Dengan demikian dapat merubah pemahaman tentang makna kewirausahaan yang akan membantu civitas akademika untuk mendeteksi dan mengevaluasi tentang program kewirausahaan pada perguruan tinggi, apakah sudah ada ? atau belum menilai penting pengembangan kewirausahaan ? Perguruan tinggi menilai penting pengembangan kewirausahaan sebagai penggerak kemampuan kreativitas dan inovatif yang akan dijadikan dasar, kiat dan sumber daya untuk mencari peluang menuju sukses dalam mengelola perguruan tinggi.

2. Problematik Proses;
Program pengembangan kewirausahaan di perguruan tinggi salah satunya adalah melalui implementasi mata kuliah kewirausahaan yang terintegrasi ke dalam kurikulum, yaitu bagaimana kurikulum dikembangkan dengan identifikasi keunikannya yang memiliki kaitan dengan pengembangan kewirausahaan. Pengembangan kurikulum kewirausahaan dapat mengadopsi dari bangunan rumah manajemen ilmu pengetahuan pada pendidikan tinggi. Lebih penting lagi untuk melihat keseriusan perguruan tinggi terhadap pengembangan kewirausahaan adalah sejauhmana kebijakan yang dikeluarkan dapat memperkuat terhadap program tersebut. Meskipun kebijakan secara khusus tentang pengembangan kewirausahaan yang terintegrasi ke dalam kurikulum belum dikeluarkan, akan tetapi dari penerapan sudah dilakukan secara parsial pada program studi yang dinilai memiliki kaitan atau tidak dengan mata kuliah kewirausahaan, hal ini melahirkan pemahaman yang berbeda pada tingkatan pimpinan program studi/jurusan dan fakultas dikarenakan tidak adanya kebijakan khusus dari Rektorat, sehingga civitas akademika belum adanya kekompakan dan keseragaman untuk menuju pada nilainilai kewirausahaan. Apabila kebijakan khusus akan dikeluarkan sesungguhnya banyak program kewirausahaan dapat dikelola oleh perguruan tinggi dari mulai yang berkaitan dengan program perkuliahan sampai pada program ekstrakurikuler atau dapat dipadukan dengan multidisiplin ilmu lainnya, dengan pandangan yang lebih komprehensif.

3. Problematik Hasil;

Menerapkan dan melaksanakan program kewirausahaan pada civitas 
akademika masih akan menghadapi kendala, karena pemahaman masingmasing perguruan tinggi berbeda. Sebagian orang merasa kurang tepat dalam memandang universitas entrepreneur yang diartikan sebagai universitas yang berwawasan bisnis, mengingat dasar filosofis pendidikan yang berorientasi pada pelayanan jasa secara nirlaba (non-profit). Padahal konsep universitas entrepreneur memandang sesuatu secara menyeluruh sebagai satu kesatuan yang saling terkait dan bersinergi. Kegiatan entrepreneurial merupakan inti dari fenomena transformasi universitas dalam menjalankan tri dharma perguruan tinggi, artinya bahwa semua unit-unit menjadi pusat bisnis di samping sebagai pusat pelayanan akademis. Jika cara pandang civitas akademika sudah mengarah pada hal tersebut, maka pengembangan kewirausahaan akan memberikan dampak yang signifikan dengan merubah pola pikir dan tata kerja civitas akademika, atau sebaliknya. Sebenarnya untuk melihat dampak pengembangan kewirausahaan akan dapat dilihat dari kinerja yang tinggi dalam pengajaran dan penelitian, atau dapat diukur pada pengembangan organisasi yang berorientasi hasil sebagai pedoman dalam pengembangan perguruan tinggi menuju entrepreneur university.

4. Problematik Strategi;

Pengembangan kewirausahaan pada perguruan tinggi diperlukan strategi dan pengembangan program gerakan budaya kewirausahaan dengan program Inkubator Bisnis (INBIS). Artinya, Inkubator Bisnis perguruan tinggi adalah suatu lembaga yang berfungsi menginkubasi potensi bisnis perguruan tinggi dan dunia usaha menuju perguruan tinggi berbasis research university sekaligus entrepreneurial university. Perguruan tinggi perlu mengembangkan unit-unit bisnis dari tingkat fakultas sampai rektorat, secara langsung inkubator bisnis perguruan tinggi tersebut adalah bagian integral dari struktur organisasi kampus karena yang akan menggerakan, mengarahkan dan mengawasi adalah pimpinan di tingkat universitas untuk unit-unit bisnis tingkat universitas, dan pimpinan tingkat fakultas dan program studi/jurusan untuk unit-unit bisnis tingkat fakultas dan program studi/jurusan.

\section{B. Rekomendasi}

Berdasarkan kesimpulan di atas dapat diungkapkan rekomendasi dari kajian tentang spirit kewirausahaan di perguruan tinggi, sebagai berikut:

1. Pemaknaan yang sempit dalam arti pemahaman praktis terhadap kewirausahaan perlu segera diubah dengan diupayakan adanya sosialisasi terpogram tentang pemaknaan kewirausahaan yang lebih luas dari makna keilmuan (transfer of knowledge) dan makna sikap (transfer of value), akan memberikan implikasi yang penting terhadap program pengembangan kewirausahaan perguruan tinggi.

2. Hendaknya perguruan tinggi untuk mengambil manfaat dikembangkannya program kewirausahaan agar secara langsung membekali mahasiswa dalam proses belajar (memperhatikan ranah kognitif, afektif dan psikomotorik) dengan nilai-nilai yang terkandung di dalam kewirausahaan yaitu cara berfikir civitas akademika lebih kreatif, mandiri dan inovatif. 
3. Pentingnya perguruan tinggi dalam mencetak lulusannya memiliki nilai tambah dalam kemampuan menciptakan peluang-peluang usaha dengan melakukan identifikasi unit-unit bisnis jika yang sudah ada dan potensi bisnis di perguruan tinggi, menyiapkan potensi bisnis di perguruan tinggi agar menjadi unit bisnis yang mandiri dan mampu menjadi income generating program, membantu civitas akademika, karyawan dan alumni dalam pengembangan kewirausahaan.

4. Adakan program kewirausahaan perguruan tinggi yang mengacu pada program-program tridharma perguruan tinggi dengan penjabarannya yang luas dan memiliki dimensi ke arah pengembangan kewirausahaan dalam pembentukan masyarakat perguruan tinggi yang selalu memiliki spirit kemandirian, inovasi dan kreativitas.

5. Pengembangan program kewirausahaan pada perguruan tinggi hendaknya dimulai dari kajian kurikulum dengan melakukan identifikasi pada setiap program studi untuk memposisikan mata kuliah kewirausahaan merupakan mata kuliah yang harus terintegrasi ke dalam kurikulum, sehingga pemahaman konsep keilmuan terhadap kewirausahaan akan lebih merata, hal ini untuk merubah pemahaman kewirausahaan dari makna yang sempit kepada pemaknaan yang lebih luas.

6. Perlunya para pengambil kebijakan pada perguruan tinggi dari tingkat universitas sampai fakultas, program studi/jurusan menyadari dengan serius terhadap pengembangan kewirausahaan akan dapat tercapai apabila adanya kebijakan yang dikeluarkan dapat memperkuat terhadap program tersebut, salah satunya jika kebijakan perguruan tinggi secara khusus menekankan adanya mata kuliah kewirausahaan yang terintegrasi pada semua struktur kurikulum jurusan/prodi atau kebijakan tentang pengembangan budaya kewirausahaan pada tingkat universitas sampai fakultas.

7. Adanya pemahaman dan pola pikir yang perlu dirubah pada civitas akademika dalam memandang penerapan dan pelaksanaan program kewirausahaan, sebagian orang memandang kurang tepat dengan konsep universitas entrepreneur karena mengingat dasar filosofis pendidikan yang berorientasi pada pelayanan jasa secara nirlaba (non-profit). Pemahaman tersebut secara bertahap akan berubah ketika menyadari semangat kewirausahaan dapat mengantisipasi persaingan yang tajam antar perguruan tinggi.

8. Penerapan program kewirausahaan perguruan tinggi salah satunya menampilkan simbol-simbol yang mendorong semangat entrepreneurship di lingkungan kampus dalam pemahaman praktis, dengan dirintis atau dikembangkannya unit-unit usaha sebagai sarana untuk memotivasi civitas akademika, sehingga ruh dan semangat kewirausahaan akan 
selalu hidup dan dinamis. Hal ini untuk menjawab bahwa pemahaman praktis atau dalam arti sempit dari pemaknaan kewirausahaan tidak dapat dipandang sebelah mata.

9. Perlunya selalu mengukur dampak program pengembangan kewirausahaan apabila diterapkan pada perguruan tinggi. Salah satu yang dapat dilihat untuk mengukur dampak keberhasilan civitas akademika sebagai dampak program kewirausahaan adalah kinerja yang tinggi dalam pengajaran dan penelitian di atas indikator lainnya.

10. Strategi dan model program kewirausahaan pada perguruan tinggi yang telah ada atau yang akan diujicobakan dari hasil penelitian ini, hendaknya dikaji lebih luas dan mendalam melalui penelitian-penelitian yang akan memperkuat, memperdebatkan atau memperluas wawasan untuk melahirkan strategi dan model baru lainnya dengan fokus kajian yang sama. Karena tujuan untuk melahirkan entrepreneurship dengan membangun spirit teknopreneurship membutuhkan proses yang panjang dan dibutuhkan strategi dan model yang dapat diterapkan.

\section{DAFTAR PUSTAKA}

Alen, Mark. (2002). The Corporate University.New York. Amacom.

Alma, B. (2009). Kewirausahaan. Bandung. Alfabeta.

Alma, B dan Hurriyati, Ratih. (2008). Manajemen Corporate dan Strategi Pemasaran Jasa Pendidikan. Bandung. Alfabeta.
Antonio, S. (2007). Muhammad SAW, The Super Leader Super Manager. Jakarta. PLM.

Clegg, Brian dan Birch, Paul. (2001). Instant Creativity. Jakarta. Erlangga.

Crombie, Roger. W. (2005). Curriculum Innovation. Jakarta. Grasindo

Daniels, Aubrey. C. (2005). Maximum Performance. Jakarta. Gramedia.

Drucker, Peter F. (1996). Inovasi dan Kewiraswastaan. Jakarta. Erlangga.

Drucker, Foundation. (2001). The Organization of The Future: Organisasi Masa Depan. Alih Bahasa oleh Ahmad Kemal. Jakarta. Gramedia.

Gasset, J. Ortega Y.(1966). Mission of the University. New York: Norton Co.

Glaser, Barney, dan Anselm L. Strauss. (1974). The Discovery of Grounded Theory: Strategies for Qualitative Research. Aldine. Chicago

Green, Andy. (2001). Kreativitas dan Public Relation. Jakarta. Erlangga.

Hisrich, Robert. D, Peter, Michael. P, Shepherd, Dean. A. (2008). Entrepreneurship. New York. Mc. Graw Hill.

Ihalauw, John. J.O.I. (2008). Konstruksi Teori: Komponen dan Proses. Jakarta. Grasindo.

Kao, Raymond. W.Y. (1997). An Entrepreneurial Approach to Corporate Management. Singapura. Prentice Hall.

Kaplan, D. dan Manners A.Robert. (2002). Teori Budaya. Yogyakarta. Pustaka Pelajar. 
Kiyosaki, Robert T. (2003). The Business School. Jakarta. Gramedia.

Kotter, John P.dan James L. Heskett. (1992). Corporate Culture and Performance. New York: The Free Press.

Margianti. (2008). Manajemen Mutu Perguruan Tinggi di Era Global. Jakarta. Gunadarma.

Maxwell, Joseph A. (1996). Qualitative Research Design An Interactive Approach. London: SAGE. Thousand Oaks.

McMillan, Schumacher. (2000). Research in Education (fifth edition). New York. Longman.

Meister, Jeanne. C. (1994). Corporate Quality Universities. New York. Irwin.

Meredith G. (2002). Kewirausahaan: Teori dan Praktek. Jakarta. PPM.

Muhadjir, N.(1989). Metodologi Penelitian Kualitatif. Yogyakarta: Rake Sarasin.

Moleong, L.J.(1989). Metodologi Penelitian Kualitatif. Bandung: Remaja Karya

Nasution, A.H., Noer, B.A. dan Suef, M. (2007). Entrepreneurship; Membangun Spirit Teknopreneurship. Yogyakarta. ANDI.

Osborne, David, dan Ted Gaebler. (1992). Reinventing Government (How The Entrepreneurial Spirit is Transforming The Public Sector). Addison-Wesley Publishing Company. Inc.

Pandji A dan Djoko S. (2002). Koperasi, Kewirausahaan, dan Usaha Kecil. Jakarta, Rineka Cipta.
Reksohadiprodjo, S dan Handoko, Hani. (2001). Organisasi Perusahaan. Yogyakarta. BPFE.

Rangkuti, F. (1999). Analisis SWOT Teknik Membedah Kasus Bisnis. Jakarta. Gramedia.

Roger, Everett dan Shoemaker, Floyd.F (1987). Communication of Innovations. Alih Bahasa oleh Abdillah Hanafi. Surabaya. Usaha Nasional.

Sathe, Vijay. (1985). Culture and Related Corporate Realities. Richard D. Irwin, Inc. Homewood, III.

Slamet, M. (2004). Prosiding Lokakarya : Merekayasa Jalan Menuju Transformasi Perguruan Tinggi. Jakarta. Forum HEDS.

Steiner, George A. (1992). Strategic Planning. Macmillan Publishing Co. Inc. United State of America.

Sugiyono. (2008). Metode Penelitian Bisnis. Bandung. Alfabeta.

Suryana. (2003). Kewirausahaan : Pedoman Praktis, Kiat dan Proses Menuju Sukses. Jakarta. Salemba Empat.

Targowski, Andrew. S. dan Tarn, Michael. J. (2007). Enterprise Systems Education in the 21st Century. USA. INFOSCI.

Tilaar, H.A.R., dan Nugroho, R. (2008). Kebijakan Pendidikan. Yogyakarta. Pustaka Pelajar.

White, Crombie. (2005). Curriculum Innovation. Alih Bahasa oleh Aprilia B. Hendrijani. Jakarta. Gramedia.

Watson. H.Gregory. (1997). Strategic Benchmarking "Mengukur Kinerja Perusahaan Anda Dibandingkan Perusahaanperusahaan Terbaik Dunia". Alih Bahasa oleh Robert Haryono Imam. Jakarta. Gremedia. 
Zohar, Danah. Dan Marshal, Ian. (2005). Spiritual Capital; Memberdayakan SQ di Dunia Bisnis. Alih Bahasa oleh Helmi Mustofa. Bandung. Mizan.

\section{Jurnal Ilmiah :}

Journal of Private Enterprise. Vol. IX, No. 2 :71. “A Typology of Entrepreneurial Styles: Beyond Economic Rationality".

\section{Sumber Lain :}

Undang-Undang Republik Indonesia. Nomor 20 Tahun 2003. Tentang Sistem Pendidikan Tinggi Nasional. Jakarta. Depdiknas.

Undang-Undang Republik Indonesia. Nomor 09 Tahun 2009. Tentang Badan Hukum Pendidikan. Jakarta. Depdiknas.

Peraturan Pemerintah Nomor 60 Tahun 1999. Tentang Perguruan Tinggi. Jakarta.

Instruksi Presiden Nomor 04 Tahun 1995. Tentang Gerakan Nasional Memasyarakatkan dan Membudayakan Kewirausahaan. Jakarta.

Depdiknas Dirjen Dikti. (2004). Strategi Jangka Panjang Pendidikan Tinggi 2003-2010 (HELTS); $\quad$ Mewujudkan Perguruan Tinggi Berkualitas. Jakarta. Depdiknas RI.

Depdiknas. (2006). Pedoman Operasional Pengembangan Model Inkubator Bisnis Perguruan Tinggi. Jakarta. Depdiknas RI.

Direktorat Kelembagaan. Dirjen Dikti. (2008). Panduan Program Mahasiswa Wirausaha (PMW). Jakarta. Depdiknas Republik Indonesia.
Badan Akreditasi Nasional. (2008). Standar Penilaian Akreditasi Perguruan Tinggi. Jakarta. BANPusat.

Ahmad, Anizir. (2001). Model Kurikulum dan Strategi Pembelajaran Pendidikan Kewiraswastaan. Hasil Penelitian. UPI Bandung.

Akbar, Sa'adun. (2000). Prinsip-prinsip dan Vektor-vektor Percepatan Proses Internalisasi Nilai Kewirausahaan. Hasil Penelitian. UPI Bandung.

Bunyamin, Ichlas. (2002). Model Pelatihan Perintisan / Pengembangan Wirausaha. Hasil Penelitian. UPI Bandung.

Ciputra. (2009). Tularkan Entrepreneurship. Radar Banten (22 April 2009).

Dirjen Dikti (2008). Data Sarjana Nganggur. Kompas (6 Februari 2008).

Evans. (2002). Menggagas Rencana Bisnis Strategis. Hasil Penelitian. UPI Bandung.

Litbang Diknas. (2005). Permasalahan Perguruan Tinggi Indonesia "The Burning Issues". Hasil Penelitian. Depdikbud. Jakarta.

Suhendraya, Hendi M. (2002). Pengembangan Model Pendidikan Kewiraswastaan dalam Muatan Lokal. Hasil Penelitian. UPI Bandung.

Wijiyanto. (2009). Merajut Kembali Entrepreneur University. Kolom Academia dari Untirta untuk Banten. Radar Banten (23 Februari 2009).

\section{Biodata Penulis}

Dr. Heri Erlangga, menyelesaikan Pendidikan formal SD, SMP, SLTA diselesaikan di kota Serang dan 
kemudian melanjutkan S1 Administrasi Negara FISIP UNPAS (1995), S2 Administrasi Pendidikan UPI Bandung (2001) S3 Administrasi Pendidikan UPI Bandung (2009). Saat ini penulis sebagai Dosen tetap pada program Studi/Jurusan Administrasi Bisnis FISIP UNPAS dan menjabat sebagai Wakil Dekan I (Bidang Akademik) FISIP UNPAS dan Sekretaris YPDM Pasundan bidang keahlian Administrasi/manajemen bisnis, leadership kewirausahaan. 